\title{
Uji Kuat Tekan dan Daya Serap pada Batako dengan Menggunakan Metode Taguchi
}

\author{
Akhmad Sutoni \\ Program Studi Teknik Industri, Fakultas Teknik, Universitas Suryakancana, Jalan Pasir Gede Raya, Cianjur, Jawa Barat, \\ 43216, Indonesia
}

\section{ARTICLE INFORMATION}

Article history:

Received: September 04, 2018

Revised: December 11, 2018

Accepted: Decemberl 24, 2018

Kata Kunci:

Daya Serap

Metode Taguchi

Orthogonal Array

Rekayasa Kualitas

Uji Tekan

\section{A B S T R A K}

Proses pembuatan batako memiliki dua karakteristik yang sangat kritis Critical To Quality (CTQ), yaitu kuat tekan dan daya serap air. Karakteristik kualitas kuat tekan semakin besar nilainya, maka semakin baik (Higher The Better). Sedangkan untuk daya serap air karakteristik kualitas semakin kecil, maka semakin baik (Smaller The Better). Kualitas batako yang digunakan sebagai bahan bangunan harus mempunyai kualitas yang bagus yang dapat mempertahankan kekuatan bangunan yang ada. Kualitas yang dimaksud adalah kuat tekan dan daya serap air yang dihasilkan harus sesuai dengan syarat-syarat SNI (Standar Nasional Indonesia). Perusahaan WS adalah pabrik yang memproduksi batako dengan permasalahan kualitas yang belum bagus. Batako yang dihasilkan rapuh. Metode yang digunakan dalam penelitian ini adalah metode Taguchi. Setting Level Factor optimal Faktor A (Lama pengadukan), Faktor B (Tekanan), Faktro C (Air), Faktor D (Pengeringan) dan Faktor E (Komposisi Pasir dan Kapur). Dimana faktor setting level factor optimal yang berpengaruh dan paling dominan pada kuat tekan dan daya serap air adalah faktor $\mathrm{E}$ (Komposisi pasir dan kapur). Untuk kuat tekan faktor $E$ (Komposisi pasir dan kapur) level 2, 1:0.25 dan untuk daya serap Faktor $E$ (komposisi pasir dan kapur) level 1, 1:0.5. dan untuk konfirmasi hasil penelitian desain eksperimen ini, maka didapat persentasi Quality Loss Function kuat tekan dan daya serap air setelah setting level optimal mengalami peningkatan kualitas sebesar $51,91 \%$ dan mengalami penurunan Loss function sebesar $78,5 \%$.

\section{A B S T R A C T}

The brick making process has two very critical characteristics / Critical To Quality (CTQ), namely compressive strength and water absorption. For the quality characteristics of the compressive strength the greater the value, the better (Higher The Better). As for the absorption of water the quality characteristics are getting smaller, the better (Smaller The Better). The quality of the brick used as building material must have good quality that can maintain the strength of existing buildings. The quality in question is the compressive strength and absorbency of water produced must be in accordance with the requirements of SNI (Indonesian National Standard). The WS companies produce concrete blocks which have not good quality. The bricks are brittle. The method used in this study is the Taguchi method Optimal Level Factor setting is Factor A (duration of stirring), Factor B (Pressure), Factor C (Water), Factor D (Drying) and Factor $E$ (Composition of Sand and Lime). Where the optimal factor setting level factor that is most influential and dominant in compressive strength and water absorption is factor $E$ (composition of sand and lime). For compressive strength factor $E$ (sand and lime composition) level 2, 1: 0.25 and for absorption factor $E$ (composition of sand and lime) level 1, 1: 0.5. and to confirm the results of this experimental design study, a percentage of Quality Loss Function of compressive strength and water absorption was obtained after the optimal level setting had a quality increase of $51.91 \%$ and a decrease in the Loss function of $78.5 \%$. 


\section{PENDAHULUAN}

Kualitas adalah salah satu faktor pertimbangan konsumen dalam memilih produk atau jasa yang mereka inginkan. Suatu industri yang mampu membuat produk atau jasa yang berkualitas memiliki peluang yang besar dalam memenangkan persaingan yang semakin ketat. Kenyataan inilah yang menjadi salah satu pendorong bagi dunia industri untuk menghasilkan produk yang berkualitas sesuai dengan spesifikasi yang diinginkan pelanggan. Untuk merealisasikan hal itu, maka pengendalian dan pengembangan kualitas harus dilaksanakan agar dapat menghasilkan produk atau jasa yang berkualitas sehingga dapat memenuhi kebutuhan dan harapan konsumen.

Peningkatan optimasi sangat penting untuk mendapatkan kualitas yang telah ditargetkan [1]. Taguchi adalah salah satu metode optimasi yang menyajikan jalur yang lebih baik untuk meningkatkan desain dan kualitas [2] dengan mengoptimalkan serangkaian parameter yang dapat dikontrol [3]. Taguchi mengadopsi loss function pada data-data hasil eksperimen untuk proses optimasi dengan prosedur yang singkat dan praktis [4]. Sasaran metode Taguchi adalah menjadikan produk robust terhadap noise. Metode Taguchi mempunyai tiga buah konsep mengenai kualitas yaitu kualitas tidak hanya sekedar memeriksa akan tetapi harus di desain dalam sistem, kualitas dapat diperoleh dengan cara meminimalkan deviasi dari target dan biaya kualitas dapat diukur sebagai fungsi deviasi dan kerugian diukur dari seluruh sistem.

Penggunaan metode Taguchi dalam produksi batako telah digunakan untuk menguji kekuatan tekan [5], daya serap, dan kekuatan tekan [6]-[9]. Penelitian ini mengadopsi penelitian produksi batako dengan tujuan untuk menguji kekuatan tekan dan daya serap. Penelitian ini bertujuan untuk mengetahui faktor yang mempengaruhi kuat tekan dan daya serap pada batako, mencari level faktor yang terbaik dalam pembuatan batako dan mengetahui optimasi peningkatan, dan penurunan loss function. Hasil penelitian ini diharapkan meningkatkan kualitas batako.

\section{METODE PENELITIAN}

Penelitian ini menggunakan tahapan metode Taguchi dalam menyelesaikan penelitian, berdasarkan data primer dan data sekunder yang telah diperoleh. Fokus penelitian ini adalah produksi batako pada Perusahaan WS. Tahapan metode Taguchi yang digunakan dalam penelitian ini terdiri dari:

a. Identifikasi karakteristik kualitas merupakan identifikasi faktor-faktor yang dianggap penting yang mempengaruhi karakteristik suatu produk (kuat tekanan dan daya serap)

b. Menentukan Faktor Kontrol dan Noise. Faktor kontrol merupakan faktor yang nilainya dapat diatur, sedangkan noise faktor merupakan faktor-faktor yang tidak dapat dikendalikan atau diatur [10].

c. Menentukan Setting Level Faktor. Setting ini berdasarkan level yang telah ditetapkan berdasarkan faktor-faktor yang akan dianalisa.

d. Menentukan Fungsi Objektif (S/N Ratio). S/N Ratio berfungsi sebagai parameter mutu untuk evaluasi dari perubahan perancangan parameter terhadap hasil produk [11]

e. Mengidentifikasi Faktor Kontrol yang Mungkin Berinteraksi. Interaksi terjadi jika faktor dipengaruhi oleh level dari faktor lain atau akan terjadi apabila kumpulan pengaruh dari dua atau lebih faktor berbeda dari jumlah masing-masing faktor secara individu [12].

f. Membuat Orthogonal Array. Orthogonal array adalah matriks keseimbangan dari beberapa percobaan yang menunjukkan penugasan faktor eksperimen [13], [14].

g. Menjalankan Eksperimen. Eksperimen dilakukan dengan melakukan sejumlah percobaan untuk mendapatkan level yang tepat untuk percobaan tersebut.

h. Menentukan Faktor yang Berpengaruh Signifikan Terhadap Nilai Rata-rata dengan Menggunakan Analysis of Variance (ANOVA).

i. Grafik Main Effect Factor. Grafik ini berfungsi untuk menggambarkan faktor-faktor yang mempunyai pengaruh terhadap kualitas yang dilakukan percobaan.

j. Menganalisis Hasil Eksperimen. Hasil eksperimen digunakan untuk mengevaluasi faktor-faktor yang mempunyai pengaruh atau tidak terhadap karakteristik kualitas yang dilakukan.

k. Melakukan Eksperimen Konfirmasi. Eksperimen konfirmasi dilakukan untuk menguji hasil yang didapatkan sesuai dengan yang diharapkan melalui pengujian dengan interval keyakinan yang telah ditentukan.

I. Perhitungan Loss Function. Fungsi kehilangan yang terjadi dari desain eksperimen baru sebagai evaluasi terhadap fungsi kehilangan sebelum dilakukan perbaikan.

m. Perhitungan Persentase Perbaikan. Perhitungan ini digunakan sebagai parameter uji coba yang dilakukan, apakah hasil eksperimen memberikan dampak yang lebih 
baik terhadap kualitas atau tidak mempunyai pengaruh yang signifikan terhadap peningkatan kualitas produk.

\section{HASIL DAN PEMBAHASAN}

Hasil dan pembahasan dalam penelitian ini mengacu pada tahapan metode Taguchi. Langkah-langkah dalam melakukan hasil dan pembahasan sesuai dengan tahapan berikut.

\section{Identifikasi Karakteristik}

Dalam penelitian ini karakterisitik kualitas yang diukur adalah kuat tekan (satuan $\mathrm{kg} / \mathrm{cm}^{2}$ ) dan daya serap air (satuan \%). Hal ini disebabkan karena karakteristik kualitas ini memiliki standar minimum yang jelas pada masing-masing tingkat mutu dibanding dengan karakteristik yang lain. Seperti yang tertera di bawah ini, Standar Nasional Indonesia (SNI) yang telah di tentukan SNI 03-0349-1989 (Tabel 1).
Tabel 1. Standar Daya Serap dan Kuat Tekan

\begin{tabular}{cccccc}
\hline \multirow{2}{*}{ Jenis } & \multirow{2}{*}{ Satuan } & \multicolumn{4}{c}{ Tingkat Mutu } \\
& & I & II & III & IV \\
\hline $\begin{array}{c}\text { Kuat } \\
\text { Tekan }\end{array}$ & $\mathrm{Kg} / \mathrm{cm}^{2}$ & 90 & & 35 & 21 \\
Daya & $\%$ & 25 & 35 & - & - \\
Serap & $\%$ & & & & \\
\hline
\end{tabular}

Sumber : SNI 03-0349-1989

\section{Menentukan Faktor Kontrol dan Noise}

Pada tahapan ini faktor-faktor yang mempengaruhi karakteristik kualitas diidentifikasi dengan cara melakukan brainstorming dengan pihak pegawai, mengenai faktor-faktor apa saja yang mempengaruhi karakteristik batako. Penelitian ini hanya dibatasi pada faktor-faktor berpengaruh terkendali, sehingga faktor-faktor yang lain dianggap tidak signifikan terhadap hasil uji kuat tekan dan daya serap. Faktor-faktor dapat diidentifikasi dengan menggunakan diagram fishbone (Gambar 1).

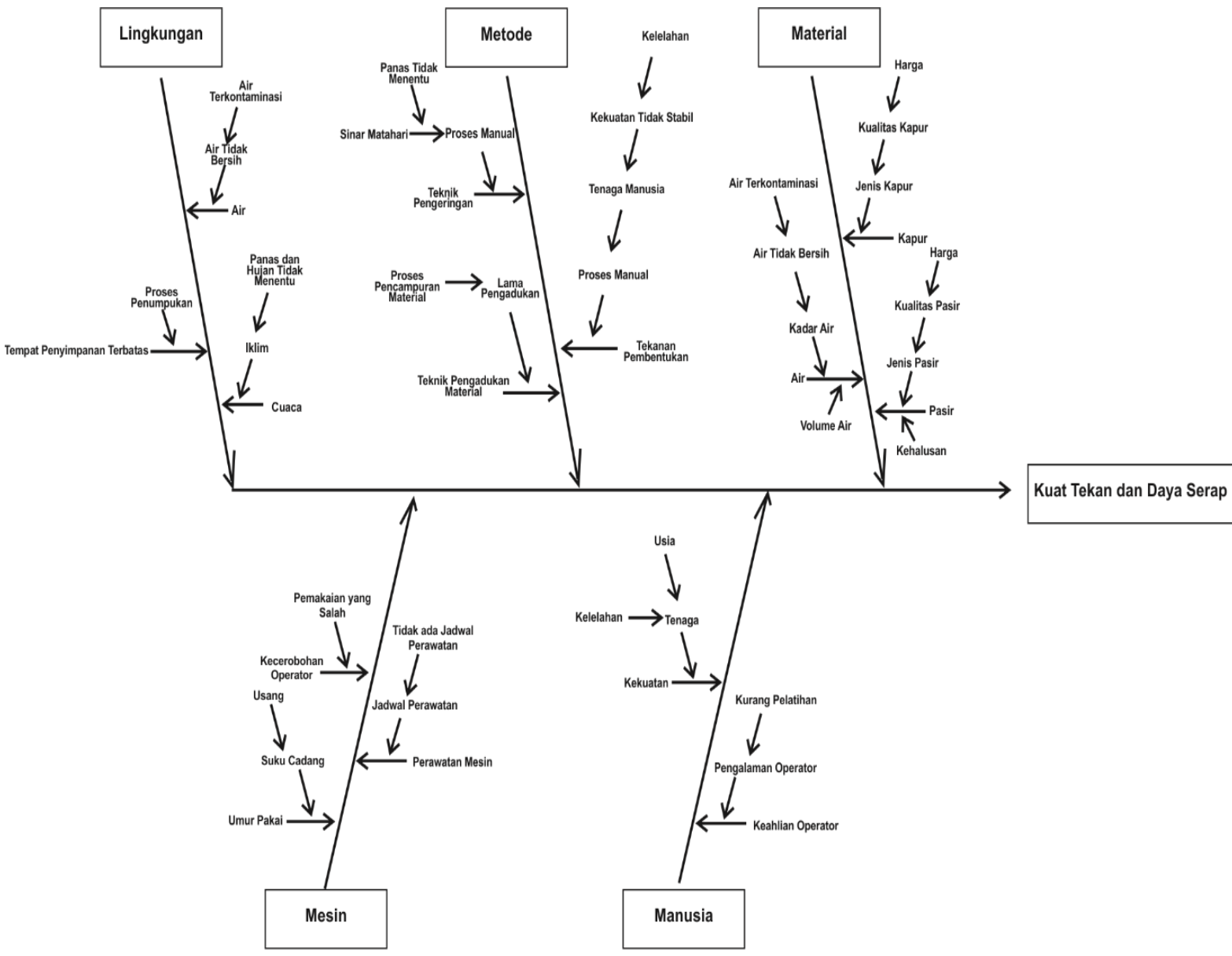

Gambar 1. Diagram Fishbone 


\section{Menentukan Setting Level Faktor}

Eksperimen yang dilakukan menggunakan dua setting level yang menunjukan level tinggi dan rendah, dalam menentukan masing-masing faktor dengan melakukan konsultasi dengan ahli yang berpengalaman. Setting level untuk faktorfaktor yang dilibatkan dalam eksperimen, berikut ini adalah tabel penugasan setting level faktor untuk eksperimen Taguchi (tabel 2).

Tabel 2. Penentuan setting level faktor kontrol

\begin{tabular}{cccc}
\hline Faktor & \multirow{2}{*}{ Keterangan } & \multicolumn{2}{c}{ Level Faktor } \\
Kontrol & & 1 & 2 \\
\hline A & Lama Adukan & 5 Menit & 10 Menit \\
B & Tekanan & $60 \mathrm{Kg}$ & $120 \mathrm{Kg}$ \\
C & Air & $10 \%$ & $15 \%$ \\
D & Lama & 4 Hari & 8 Hari \\
& Pengeringan & & \\
E & Komposisi & $1: 0,5$ & $1: 0,25$ \\
\hline & (Pasir:Kapur) & & \\
\hline
\end{tabular}

\section{Menentukan Fungsi Objektif (S/N Ratio)}

Rasio S/N adalah indikator kualitas yang menunjukkan hamburan di sekitar nilai target [15]. Ada tiga jenis karakteristik kualitas dalam analisis rasio $\mathrm{S} / \mathrm{N}$, yaitu semakin rendah semakin baik, semakin tinggi semakin baik, dan nominalyang-terbaik [16], [17] .Dalam penelitian ini, rasio $\mathrm{S} / \mathrm{N}$ yang digunakan adalah higher is better untuk kuat tekan, karena semakin besar kuat tekan yang didapat maka semakain bagus kualitas yang dihasilkan dan smaller is better untuk daya serap karena semakin kecil daya serap yang dihasilkan maka semakin bagus kualitas yang dihasilkan.

\section{Mengidentifikasi Faktor Kontrol yang Mungkin Berinteraksi}

Berikut ini merupakan tabel interaksi antara faktor A dan B untuk kuat tekan (Tabel 3).

Tabel 3. Interaksi antara Faktor A dan B kuat Tekan

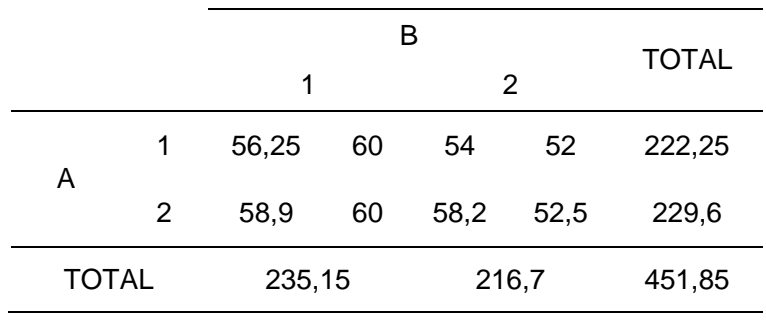

Data interaksi di atas diolah dengan Uji ANOVA 2 arah interaksi dengan menggunakan software SPSS. Berikut ini tabel hasil perhitungan Nilai $F$ untuk Faktor A dan B Kuat tekan (Tabel 4).
Tabel 4. Perhitungan Nilai $F$ untuk Faktor $A$ dan B kuat Tekan

\begin{tabular}{ccccc}
\hline Source & $\begin{array}{c}\text { Sum of } \\
\text { Squares }\end{array}$ & df & $\begin{array}{c}\text { Mean } \\
\text { Square }\end{array}$ & $\mathrm{F}$ \\
\hline Faktor A & 6,735 & 1 & 6,735 & 1,044 \\
Faktor B & 42,55 & 1 & 42,55 & 6,576 \\
Faktor A* Faktor B & 525 & 1 & 525 & 81 \\
Eror & 25,881 & 4 & 6,47 & \\
Total & 25596,763 & 8 & & \\
Connected Total & 75,71 & 7 & & \\
\hline
\end{tabular}

Struktur hipotesis

$\mathrm{H}_{\mathrm{o}} \quad$ : Adanya Pengaruh yang signifikan

$\mathrm{H}_{1} \quad$ : Tidak ada pengaruh yang signifikan

$\mathrm{H}_{0} \Omega_{-}((\mathrm{A} \& \mathrm{~B})) \quad$ : Ada interaksi antar faktor

$\left.\mathrm{H}_{1}\right]_{-}((\mathrm{A} \& \mathrm{~B})) \quad$ : Tidak ada interaksi antar faktor Wilayah kritis

Untuk Faktor A (Gambar 2)

v1 :1 (derajat kebebasan kolom)

v2 : 4 (derajat kebebasan error)

$f_{-(a(1,4))}: 7,71$ (dari $F$ tabel)

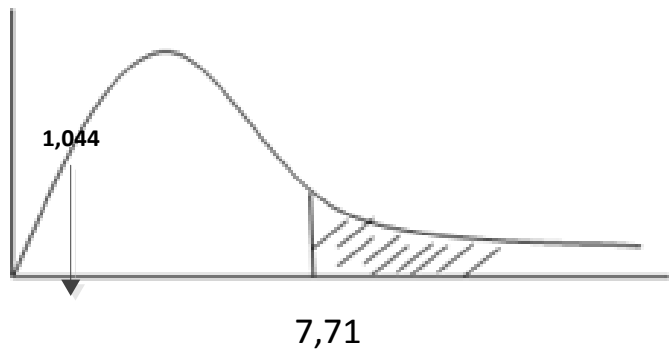

Gambar 2. Wilayah Kritis Faktor A

Untuk Faktor B (Gambar 3)

$\checkmark \quad: 1$ (derajat kebebasan kolom)

v2 :4 (derajat kebebasan error)

$f_{-}(a(1,4)): 7,71$ (dari F tabel)

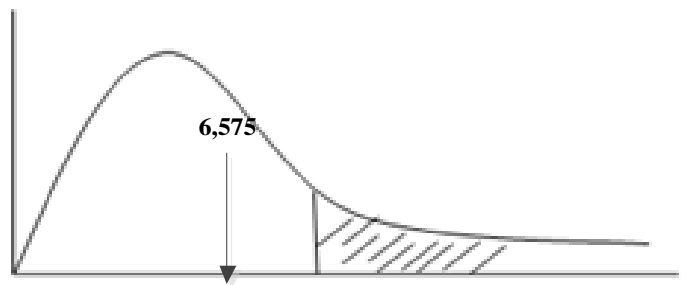

7,71

Gambar 3. Wilayah Kritis Faktor B

Untuk Faktor A dan B (Gambar 4)

$v 1: 1$ (derajat kebebasan kolom)

v2: 4 (derajat kebebasan error)

$f_{a(1,4)}: 7,71$ (dari $\mathrm{F}$ tabel) 


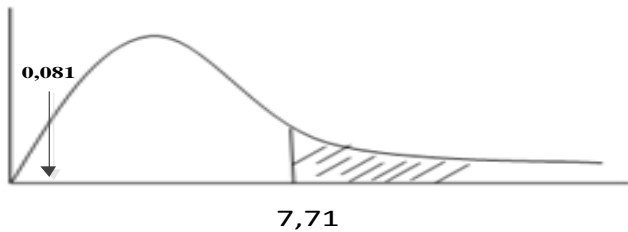

Gambar 4. Wilayah Kritis Faktor A dan B

Keputusan dan Kesimpulan

Faktor A : Tolak Ho bahwa tidak ada pengaruh dari lama pengadukan

Faktor B : Tolak Ho bahwa tidak ada pengaruh dari tekanan pembentukan

Interaksi A dan B : Tolak Ho bahwa tidak ada interaksi antara faktor $\mathrm{A}$ dan $\mathrm{B}$

1. Untuk perhitungan interaksi antara Faktor A dan B untuk daya serap dilakukan langkah perhitungan sama dengan kuat tekan

Diperoleh kesimpulan dari hasil perhitungan interaksi antara dua faktor dengan ANOVA dua arah sebagai berikut :

2. Untuk kuat tekan
a. Adanya pengaruh dari faktor A (Lama adukan)
b. Adanya pengaruh dari faktor (Tekanan)
c. Adanya pengaruh dari faktor C (Air)
d. Adanya pengaruh dari faktor (pengeringan)

e. Adanya pengaruh dari faktor $E$ (Komposisi pasir dan kapur)

f. Adanya interaksi dari faktor B (Tekanan) dan $\mathrm{E}$ (Komposisi pasir dan kapur)

g. Adanya interaksi dari faktor C (Air) dan D (Pengeringan)

\section{Membuat Orthogonal Array}

Orthogonal array dirancang kedalam suatu matriks, dimana rancangan matriks tersebut ditentukan berdasarkan banyaknya derajat kebebasan (degree of freedom). Berikut ini merupakan derajat kebebasan faktor kontrol (tabel 5):

Tabel 5. Derajat Kebebasan

\begin{tabular}{cccc}
\hline \multicolumn{4}{c}{ Derajat Kebebasan } \\
\multicolumn{2}{c}{ Kuat Tekan } & \multicolumn{2}{c}{ Daya Serap } \\
\hline A & 1 & A & 1 \\
B & 1 & B & 1 \\
C & 1 & C & 1 \\
D & 1 & D & 1 \\
B\&E & 1 & B\&E & 1 \\
C\&D & 1 & C\&D & 1 \\
\hline Total & 7 & Total & 7 \\
\hline
\end{tabular}

Berdasarkan hasil perhitungan di atas maka diperoleh derajat kebebasan sebanyak 7, maka matriks orthogonal array yang dipilih adalah L8 (Tabel 6).

Tabel 6. Orthogonal Array Eksperimen

\begin{tabular}{cccccccc}
\hline \multirow{2}{*}{ Trial } & \multicolumn{7}{c}{ Kolom No } \\
& 1 & 2 & 3 & 4 & 5 & 6 & 7 \\
\hline 1 & 1 & 1 & 1 & 1 & 1 & 1 & 1 \\
2 & 1 & 1 & 1 & 2 & 2 & 2 & 2 \\
3 & 1 & 2 & 2 & 1 & 1 & 2 & 2 \\
4 & 1 & 2 & 2 & 2 & 2 & 1 & 1 \\
5 & 2 & 1 & 2 & 1 & 2 & 1 & 2 \\
6 & 2 & 1 & 2 & 2 & 1 & 2 & 1 \\
7 & 2 & 2 & 1 & 1 & 2 & 2 & 1 \\
8 & 2 & 2 & 1 & 2 & 1 & 1 & 2 \\
\hline
\end{tabular}

\section{Menjalankan Eksperimen}

Berdasarkan Orthogonal Array di atas, maka dilakukan eksperimen, di bawah ini merupakan hasil eksperimen yang diperoleh (Tabel 7 dan Tabel 8).

Tabel 7. Orthogonal Array Hasil Eksperimen Kuat Tekan

\begin{tabular}{cccccccccc}
\hline $\begin{array}{c}\text { Trial } \\
\text { No }\end{array}$ & B & E & BxE & C & D & CxD & A & Kuat Tekan \\
\hline 1 & 1 & 1 & 1 & 1 & 1 & 1 & 1 & 48 & 52 \\
2 & 1 & 1 & 1 & 2 & 2 & 2 & 2 & 56,25 & 58,5 \\
3 & 1 & 2 & 2 & 1 & 1 & 2 & 2 & 97,5 & 92 \\
4 & 1 & 2 & 2 & 2 & 2 & 1 & 1 & 82,5 & 91,25 \\
5 & 2 & 1 & 2 & 1 & 2 & 1 & 2 & 87,5 & 82,5 \\
6 & 2 & 1 & 2 & 2 & 1 & 2 & 1 & 72 & 68 \\
7 & 2 & 2 & 1 & 1 & 2 & 2 & 1 & 60 & 62 \\
8 & 2 & 2 & 1 & 2 & 1 & 1 & 2 & 82,5 & 91 \\
\hline
\end{tabular}

Tabel 8. Orthogonal Array Hasil Eksperimen Daya Serap

\begin{tabular}{cccccccccc}
\hline $\begin{array}{c}\text { Trial } \\
\text { No }\end{array}$ & C & D & CxD & E & CxE & A & B & Daya Serap \\
\hline 1 & 1 & 1 & 1 & 1 & 1 & 1 & 1 & 20 & 17 \\
2 & 1 & 1 & 1 & 2 & 2 & 2 & 2 & 12 & 11 \\
3 & 1 & 2 & 2 & 1 & 1 & 2 & 2 & 17 & 14 \\
4 & 1 & 2 & 2 & 2 & 2 & 1 & 1 & 25 & 20 \\
5 & 2 & 1 & 2 & 1 & 2 & 1 & 2 & 15 & 13 \\
6 & 2 & 1 & 2 & 2 & 1 & 2 & 1 & 16 & 14 \\
7 & 2 & 2 & 1 & 1 & 2 & 2 & 1 & 22 & 18 \\
8 & 2 & 2 & 1 & 2 & 1 & 1 & 2 & 26 & 20 \\
\hline
\end{tabular}

Pengolahan data untuk ANOVA terhadap nilai variansi dimulai dengan melakukan konversi data eksperimen menjadi $\mathrm{S} / \mathrm{N}$, karakteristik kualitas 
dalam penelitian ini menggunakan higher the better dan smaller the better sehingga rumus yang digunakan adalah sebagai berikut :

\section{higher the better}

$S / N_{H B}=-10 \log \left(\frac{1}{r} \sum_{i=1}^{r} \frac{1}{y_{1}^{2}}\right)$

\section{smaller the better}

$S / N_{S T B}=-10 \log \left(\frac{1}{n} \sum_{i=1}^{n} \frac{1}{y_{1}^{2}}\right)$

Perhitungan Signal Noise Ratio merupakan teknik pemilihan karakteristik mutu yaitu berupa tingkat kekuatan tekan $(\mathrm{kg} / \mathrm{cm} 2)$ dengan fungsi obyeknya Higher The Better (HB), terpilih dalam penghitungan S/NR karena karakteristik kualitas semakin besar nilainya, maka semakin baik. Dalam percobaan ini mempunyai arti bila hasil percobaan mempunyai nilai kekuatan tekan $(\mathrm{kg} / \mathrm{cm} 2)$ yang besar maka nilai S/NR semakin baik (tabel 9).

Tabel 9. Hasil Perhitungan S/NR untuk Eksperimen

\begin{tabular}{cccccccccccc}
\hline $\begin{array}{c}\text { Trial } \\
\text { No }\end{array}$ & \multicolumn{1}{c}{ в } & E & BxE & С & D & C×D & A & Kuat Tekan & $\begin{array}{c}\text { Rata- } \\
\text { rata }\end{array}$ & SNR \\
\hline 1 & 1 & 1 & 1 & 1 & 1 & 1 & 1 & 48 & 52 & 50 & 32,31 \\
2 & 1 & 1 & 1 & 2 & 2 & 2 & 2 & 56,25 & 58,5 & 57,38 & 33,46 \\
3 & 1 & 2 & 2 & 1 & 1 & 2 & 2 & 97,5 & 92 & 94,75 & 37,67 \\
4 & 1 & 2 & 2 & 2 & 2 & 1 & 1 & 82,5 & 91,25 & 86,88 & 37,13 \\
5 & 2 & 1 & 2 & 1 & 2 & 1 & 2 & 87,5 & 82,5 & 85 & 36,73 \\
6 & 2 & 1 & 2 & 2 & 1 & 2 & 1 & 72 & 68 & 70 & 35,05 \\
7 & 2 & 2 & 1 & 1 & 2 & 2 & 1 & 60 & 62 & 61 & 33,93 \\
8 & 2 & 2 & 1 & 2 & 1 & 1 & 2 & 82,5 & 91 & 86,75 & 37,12 \\
\hline
\end{tabular}

Dari hasil perhitungan di atas maka didapat perhitungan dalam menetukan efek tiap faktor kendali supaya mendapat hasil akhir dan menetukan parameter terbaik dalam rangka pencapaian target (tabel 10).

Tabel 10. Tabel Respon untuk Nilai SNR Eksperimen Optimal

\begin{tabular}{cccccc}
\hline & A & B & C & D & E \\
\hline Level 1 & 66,96875 & 72,25 & 72,6875 & 74,5313 & 65,5938 \\
Level 2 & 80,96875 & 75,6875 & 75,25 & 75,375 & 82,3438 \\
Selisih & 14 & 3,4375 & 2,5625 & 0,84375 & 16,75 \\
\hline Rangking & 2 & 3 & 5 & 4 & 1 \\
\hline
\end{tabular}

\section{Grafik Main Effect Factor}

Penentuan faktor-faktor yang berpengaruh secara signifikan terhadap kualitas, dapat dilihat dalam grafik main effect factor. Grafik didapat dari tabel respon untuk nilai SNR eksperimen optimal (Gambar 6, 7 dan 8).

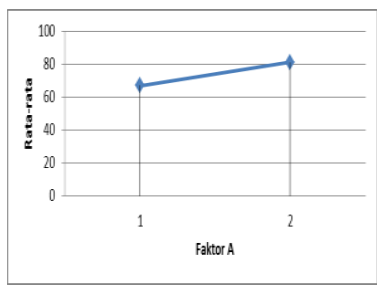

Gambar 5. Grafik Main Effect Factor A

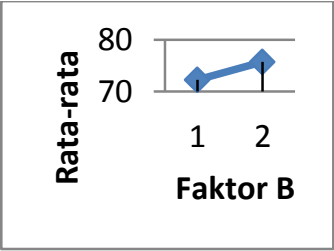

Gambar 6. Grafik Main Effect Factor B

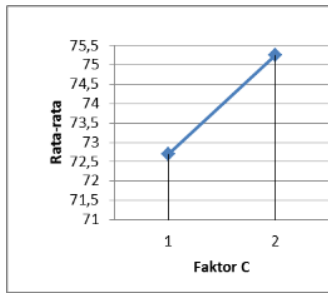

Gambar 7. Grafik Main Effect Factor C

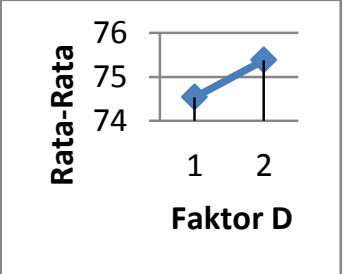

Gambar 8. Grafik Main Effect Factor D

\section{Menganalisis Hasil Eksperimen}

Setelah melakukan perhitungan dengan menggunakan ANOVA dan membut grafik main effect factor maka dapat diketahui setting level yang sesuai untuk meningkatkan kualitas batako pada tingkat mutu (Tabel 11 dan 12).

Tabel 11. Hasil Setting Level Factor Optimal Kuat Tekan

\begin{tabular}{llcc}
\hline \multicolumn{1}{c}{ Faktor } & Level & Keterangan \\
\hline A. Lama Pengadukan & 2 & 10 Menit \\
B. Tekanan & 2 & $120 \mathrm{Kg}$ \\
C. Air & 2 & 15 \\
D. Pengeringan & 2 & 8 Hari \\
E. Komposisi pasir dan & 2 & $1: 0,25$ \\
& & \\
\hline
\end{tabular}


Tabel 12. Hasil Setting Level Factor Optimal Daya Serap

\begin{tabular}{lcc}
\hline \multicolumn{1}{c}{ Faktor } & Level & Keterangan \\
\hline A Lama Pengadukan & 2 & 10 Menit \\
B Tekanan & 2 & $120 \mathrm{Kg}$ \\
C Air & 1 & 10 \\
D Pengeringan & 1 & 4 Hari \\
E Komposisi pasir dan kapur & 1 & $1: 0,5$
\end{tabular}

Eksperimen Konfirmasi

Setelah melakukan perhitungan dengan menggunakan uji ANOVA maka dapat diketahui setting level factor untuk masing-masing faktor, kemudian dilakukan percobaan konfirmasi dengan menggunakan setting level yang telah ditentukan (Tabel 13).
Tabel 13. Data Percobaan Konfirmasi

\begin{tabular}{ccc}
\hline Percobaan & Kuat Tekan $(\mathrm{Kg})$ & Daya Serap $(\%)$ \\
\hline 1 & 75 & 9 \\
2 & 90 & 6 \\
3 & 82,5 & 10 \\
4 & 75 & 10 \\
5 & 78,5 & 7 \\
6 & 82,5 & 10 \\
7 & 82,5 & 12 \\
8 & 75 & 5 \\
9 & 75 & 11 \\
10 & 82 & 10 \\
\hline Rata-rata & 79,8 & 9,0 \\
Standar Deviasi & 25,0 & 5,1 \\
\hline
\end{tabular}

Tabel 14. Perhitungan Loss Function

\begin{tabular}{ccccccccc}
\hline & \multicolumn{2}{c}{ Data Hostorik } & \multicolumn{2}{c}{ Loss Function } & \multicolumn{2}{c}{ Data Historik } & \multicolumn{2}{c}{$\begin{array}{c}\text { Loss Function } \\
\text { Konfirmasi }\end{array}$} \\
Sampel & $\begin{array}{c}\text { Kuat } \\
\text { Tekan } \\
\left(\mathrm{Kg} / \mathrm{cm}^{2}\right)\end{array}$ & $\begin{array}{c}\text { Daya } \\
\text { Serap } \\
(\%)\end{array}$ & $\begin{array}{c}\text { Kuat } \\
\text { Tekan } \\
\left(\mathrm{Kg} / \mathrm{cm}^{2}\right)\end{array}$ & $\begin{array}{c}\text { Daya } \\
\text { Serap } \\
(\%)\end{array}$ & $\begin{array}{c}\text { Kuat } \\
\text { Tekan } \\
\left(\mathrm{Kg} / \mathrm{cm}^{2}\right)\end{array}$ & $\begin{array}{c}\text { Daya } \\
\text { Serap } \\
(\%)\end{array}$ & $\begin{array}{c}\text { Kuat } \\
\text { Tekan } \\
\left(\mathrm{Kg} / \mathrm{cm}^{2}\right)\end{array}$ & $\begin{array}{c}\text { Daya } \\
\text { Serap } \\
(\%)\end{array}$ \\
\hline 1 & 45 & 19 & 0,0005 & 0,0028 & 75 & 9 & 0,0001 & 0,012 \\
2 & 30 & 21 & 0,0011 & 0,0023 & 90 & 6 & 0,0001 & 0,027 \\
3 & 34 & 15 & 0,0009 & 0,0044 & 82,5 & 10 & 0,0001 & 0,01 \\
4 & 30 & 21 & 0,0011 & 0,0023 & 75 & 10 & 0,0002 & 0,01 \\
5 & 34 & 19 & 0,0009 & 0,0028 & 78,5 & 7 & 0,0002 & 0,020 \\
6 & 47,5 & 17 & 0,0004 & 0,0035 & 82,5 & 10 & 0,0001 & 0,01 \\
7 & 45 & 13 & 0,0005 & 0,0059 & 82,5 & 12 & 0,0001 & 0,007 \\
8 & 45 & 16 & 0,0005 & 0,0039 & 75 & 5 & 0,0002 & 0,04 \\
9 & 38,2 & 19 & 0,0007 & 0,0028 & 75 & 11 & 0,0002 & 0,008 \\
10 & 35 & 19 & 0,0008 & 0,0029 & 82 & 10 & 0,0001 & 0,01 \\
\hline \multicolumn{7}{l}{ Total Loss Function } & 0,0074 & 0,0333 \\
\hline
\end{tabular}

\section{Loss Function}

Perhitungan loss function dilakukan untuk mengetahui seberapa besar loss yang diperoleh perusahaan setelah menggunakan teknik/setting level baru. Hal ini dilakukan dengan membandingkan loss function sebelum dan sesudah menggunakan setting level baru. Dari hasil perhitungan loss function (Tabel 14), dapat diketahui bahwa terjadi perubahan loss setelah menggunakan kombinasi level yang baru.

\section{Perhitungan Persentase Perbaikan}

Dari hasil perhitungan uji hipotesis,maka dapat diketahui bahwa terjadi peningkatan kualitas setelah menggunakan setting level yang baru. Oleh karena itu dapat dihitung persentase ratarata perbaikan kualitas.

$$
\begin{aligned}
& =\frac{(\text { rata }- \text { rata data konfirmasi })-(\text { rata }- \text { rata data historik })}{\text { rata }- \text { rata data konfirmasi }} \\
& =\frac{79,8-38,37}{79,8} \\
& =51,91 \%
\end{aligned}
$$

Dari perhitungan di atas maka dapat disimpulkan terjadi peningkatan kualitas kuat tekan batako sebesar $51,91 \%$

$$
\begin{aligned}
& =\frac{(\text { rata }- \text { rata data historik })-(\text { rata }- \text { rata data konfirmasi })}{\text { rata }- \text { rata data historik }} \\
& =\frac{0,001586339-0,00737864}{0,001586339}=78,5 \%
\end{aligned}
$$

Dari perhitungan di atas maka disimpulkan bahwa terjadi penurunan loss function sebesar $78,5 \%$. 


\section{KESIMPULAN}

Berdasarkan hasil penelitian ini dapat diambil beberapa hasil yaitu faktor-faktor setting level yang memberikan pengaruh paling dominan pada kuat tekan dan daya serap adalah faktor $\mathrm{E}$ (Komposisi pasir dan Kapur). Setting level optimal kualitas kuat desak batako dengan lama pengadukan 10 menit, tekanan $120 \mathrm{~kg}$ dengan komposisi pasir dan kapur sebesar 1:0,5. Quality loss function kuat tekan dan daya serap setelah setting level optimal mengalami peningkatan kualitas sebesar $51,91 \%$ dan mengalami penurunan loss function sebesar $78,5 \%$.

\section{DAFTAR PUSTAKA}

[1] M. Arsenović, Z. Radojević, Ž. Jakšić, and L. Pezo, "Mathematical approach to application of industrial wastes in clay brick production-Part II: Optimization," Ceram. Int., vol. 41, no. 3, pp. 4899-4905, 2015.

[2] A. Zirehpour, A. Rahimpour, M. Jahanshahi, and M. Peyravi, "Mixed matrix membrane application for olive oil wastewater treatment: Process optimization based on Taguchi design method," J. Environ. Manage., vol. 132, pp. 113-120, 2014.

[3] N. S. Rajput, D. D. Shukla, L. Ishan, and T. K. Sharma, "Optimization of Compressive Strength of Polymer Composite Brick Using Taguchi Method," in Soft Computing: Theories and Applications, Springer, 2018, pp. 453459.

[4] M. A. Hadiyat, "Response-surface dan Taguchi: Sebuah alternatif atau kompetisi dalam optimasi secara praktis," in Prosiding Seminar Nasional Industrialisasi Madura, 2012, pp. 134-139.

[5] R. Wawolumaja and R. Faurika "Penerapan Taguchi Parameter Design dalam Penentuan Level Faktor Produksi Batako untuk Memaksimumkan Kekuatan Tekan (Studi Kasus di Balai Besar Keramik)," Zenit, vol. 1, no. 2, pp. 99-113, 2015.

[6] A. Sutoni and D. Gunawan, "Analisis Daya Serap dan Daya Tekan Batako Pres, Terhadap Interaksi Faktor Pekerja, Faktor Komposisi Air, dan Faktor Komposisi Kapur-Pasir," J. Media Tek. dan Sist. Ind., vol. 2, no. 1, pp. 39-44, 2018.

[7] W. Setyawan and I. Saefurrohman,
"Analisis Kepuasan Pelanggan Terhadap Kualitas Batako Dengan Menggunakan Metode Taguchi-Kano," J. Media Tek. dan Sist. Ind., vol. 2, no. 2, pp. 56-64, 2018.

[8] T. Murniati, S. Sunaryo, and L. Aridinanti, "Optimasi Taguchi Multirespon melalui Pendekatan Fungsi Desirability dengan Regresi Fuzzy pada Kasus Kuat Tekan dan Daya Serap Air Produk Batako," J. Sains dan Seni ITS, vol. 4, no. 1, pp. D19-D24, 2015.

[9] A. Sutoni, W. Setyawan, and D. Gunawan, "Penerapan Metode Taguchi Dalam Interaksi Komposisi Batako Pres Terhadap Kualitas Daya Serap Dan Daya Tekan Batako," J. Telemat., pp. 15-20, 2018.

[10] M. Hartono, "Meningkatkan mutu produk plastik dengan metode taguchi," J. Tek. Ind., vol. 13, no. 1, pp. 93-100, 2012.

[11] D. P. Sari and S. A. Kusumo, "Evaluasi Pemilihan Supplier Terbaik Menggunakan Metode Taguchi Loss Functions Dan Analytical Hierarchy Process Di PT Indomaju Textindo Kudus," J@ ti Undip J. Tek. Ind., vol. 6, no. 3, pp. 161-170, 2011.

[12] A. Ishak, "Rekayasa Kualitas," Universitas Sumatera Utara, 2002.

[13] V. K. Vankanti and V. Ganta, "Optimization of process parameters in drilling of GFRP composite using Taguchi method," J. Mater. Res. Technol., vol. 3, no. 1, pp. 35-41, 2014.

[14] E. Suparti, R. W. Damayanti, and E. Pujiyanto, "Penentuan setting level optimal pada pemanfaatan abu sekam padi untuk meningkatkan kualitas paving block menggunakan metode eksperimen Taguchi," in Prosiding Seminar Nasional Teknoin, 2008, pp. C52-C59.

[15] R. K. Pandey and S. S. Panda, "Multiperformance optimization of bone drilling using Taguchi method based on membership function," Measurement, vol. 59, pp. 9-13, 2015.

[16] A. Gupta, H. Singh, and A. Aggarwal, "Taguchi-fuzzy multi output optimization (MOO) in high speed CNC turning of AISI P-20 tool steel," Expert Syst. Appl., vol. 38, no. 6, pp. 6822-6828, 2011.

[17] T. Kivak, "Optimization of surface roughness and flank wear using the Taguchi method in milling of Hadfield steel with PVD and CVD coated inserts," Measurement, vol. 50, pp. 19-28, 2014. 